\title{
The Symbolic Power Of Color: Constructions Of Race, Skin-Color, And Identity In Brazil
}

Marcia Mikulak

University of North Dakota, marcia.mikulak@und.edu

How does access to this work benefit you? Let us know!

Follow this and additional works at: https://commons.und.edu/anth-fac

Part of the Anthropology Commons

\section{Recommended Citation}

Marcia Mikulak. "The Symbolic Power Of Color: Constructions Of Race, Skin-Color, And Identity In Brazil" (2011). Anthropology Faculty Publications. 5.

https://commons.und.edu/anth-fac/5

This Article is brought to you for free and open access by the Department of Anthropology at UND Scholarly Commons. It has been accepted for inclusion in Anthropology Faculty Publications by an authorized administrator of UND Scholarly Commons. For more information, please contact und.commons@library.und.edu. 


\title{
The Symbolic Power of Color: Constructions of RACE, Skin-Color, AND IDENTITY IN BRAZIL
}

\author{
Marcia L. Mikulak \\ University of North Dakota
}

\begin{abstract}
Some current cultural anthropologists define race as a social construct, yet explorations of the socio-historical constructions that give form and structure to racial identities perpetuating notions of "race" are rarely discussed. This study explores the theory of racial formations proposed by Michael Omi and Howard Winant as it applies to Brazil's racial project, arguing that Brazil's rhetoric on race and national identity during the late 19th to early 20th century culminated in a racial project ultimately known as democracia racial. As a result, I propose that Brazilian racial consciousness is symbolically pluralistic, encompassing race, social class, and social position, generating a particularly virulent, yet silent form of racism. I expand upon racial formation theory through analysis of my fieldwork carried out in Belo Horizonte, Minas Gerias, in 2004. This analysis illustrates how contemporary Brazilian social structure and daily cultural discourses on race, skin-color, racial identity, and social marginalization reflect the nation's early racist ideology, yet contest its reality. Informants discuss self-identifications of skin-color, the meanings attributed to color tonalities, and the impact racism has on their daily lives.
\end{abstract}

\section{REFLEXIVE STATEMENT}

For the majority of my childhood and adolescent years, I lived near Sacramento, California, growing up in a military family; however, between the ages of three and seven, my father was stationed in Rio de Janeiro, Brazil during the Getulio Vargas era in the early to mid-1950s. The four years that I spent in Brazil not only made a strong impression on me, but also provided me with a life-long connection to Brazil, the people, and the Portuguese language. As an undergraduate student during the late 1960s and 1970s, I had strong relationships with a variety of impressive African American jazz musicians in the San Francisco Bay Area, and one of my first strong romantic relationships was with a Black musician. My memories of the civil rights movement and of the treatment that I received as a young white women in a relationship with a Black man has remained with me, and has led me to question the root causes of racism, inequality, and violence in mid-to late 20th century America. During my doctoral research in anthropology in Brazil with street and working youth, I was once again in Rio de Janeiro (1998 to 2000) where I became aware of the "racial" demographics that describe the majority of street and working youth. The prevalence of darker-skinned Afro-Brazilian children and youth who work the streets of Brazil's metropolitan areas struck me as significant, and I wondered why so little social science research had focused on racial issues in Brazil. Since my field work continues to explore the intersections between human rights, racism, violence, and identity, this article grew out of my doctoral research with 
darker-skinned Afro-Brazilian youth in Minas Gerais, Brazil.

"The Negro" brings everything related to poverty, to being a servant, - because the idea of being Negro is the question of being a servant, a subordinate. What is the image of the Negro? A beast-of-burden. Who will ever be proud of being a beast-of-burden? I mean, the Brazilian consciousness about who the Negro is, is really what needs to be changed" (State School Professora, 2004).

The above quotation demonstrates the frustration and anger expressed by an Afro-Brazilian state school professor during a focus group discussion that I conducted on "race" in Belo Horizonte, Brazil, in 2004. Her words exemplify the sentiments held by many who experience racial discrimination in Brazil. Such sentiments frequently remain within the private realm of personal experience and private discourse. While numerous social science texts have been published that disparage Brazil's democracia racial, ${ }^{3}$ this myth continues to persist (Burdick 1998; Hanchard 1994, 1999; Lovell 2000; Marx 1998; Reichmann 1999; Sansone 2003 Schwarcz 1999; Skidmore 1995;Telles 2004; Twine 1998). A complex socio-historical "racial" paradigm continues to inform Brazilian national social policies and popular public discourses about skin color and biological phenotypes. Ninteenth century scientific notions of race as a biological reality used to classify human populations into categories and evolutionary hierarchies are no longer credible. However, popular (folk) discourses that attribute race to skin-color, phenotypical appearances, and social hierarchies continue to direct race relations in Brazil. This paper is a compendium of socio-historical evidence and current ethnographic data that I collected in 2004 on how the Brazilian racial project of democracia racial is reflected, reproduced, and challenged in the everyday discourse of Brazilians.

As a doctoral student in anthropology who conducted research with streetandworking children in Rio de Janeiro and in Curvelo, Minas Gerais, (from 1998 to 2000), and again in 2004, I became aware of the effects of "race" on my research participants and Brazilian friends. My field-notes and observations recorded evidence of racial discrimination that were based on both skin-color and phenotypical appearances. For example, the stereotypes and common Brazilian Portuguese terms (moleque, trombadinha, and pivete ${ }^{4}$ ) that are used to define street children are pejorative (Stephens 1999; Mikulak 2002). When asking the children with whom I worked (96 percent of whom were darkerskinned phenotypical Afro-Brazilians) if they could explain what racism is, they defined it as being treated in ways that robbed them of their rights (to have a home, food, a family, an education, and to be treated fairly). Yet, when these same children were asked if they experienced racism, they could not identify personal experiences with racism, and would usually respond that, "Brazil doesn't have racism; that happens in America!" or, "In Brazil, we're a mixture of everything, so there's no racism here!" Many of these children lacked basic health care, were often undernourished, and most worked on the streets in the informal market before or after school, and some did not attend school due to their economic need to work (Mikulak 2002).

Anthropologist Robin Sheriff (2000) argues that social scientists have focused on the "loud places of history," assuming that public discourses about everyday 
life reveal topics of importance. According to Sheriff, it is about that which we do not speak that is both under-recognized and under-studied by anthropologists and other social scientists: silence is socially experienced and culturally codified, and requires tacitly shared understandings that result in unconscious complicity (Sheriff 2000:114). Granted, such complicity does not necessarily imply a lack of consciousness about discrimination based on race (or any other identifier), but it does corral sentiments of anger and frustration into the realm of forbidden topics for public discourse. Over time, my investigative questioning of working children began to unravel the façade of democracia racial. When discussing race, inequality, and marginalization with the parents of my child informants, they felt at liberty to speak about their experiences of social exclusion and racial discrimination (Mikulak 2007b). Socially silenced "places" are the habitat in which hegemony thrives, successfully cloaking the oppressive practices from all social groups living within its grasp, but nonetheless finding purchase in individual and collective consciousness. Within the privacy of their home or in a casual discussion with close friends are the settings where the myth of democracia racial is candidly challenged.

In 2004, I returned to Brazil to study the symbolic meanings of skin-color terms and racial discrimination. Again, my data from focus groups and through daily conversations with research participants confirmed the practice of everyday silent racism, and supported Sheriff's findings. The lack of public discourse about "race" and racism in educational institutions and public media outlets is a cultural practice that assists in ensuring the collective compliance to a powerfully constructed Brazilian identity: the belief and practice of democracia racial. Carefully crafted by the Brazilian "elites" after the abolition of slavery, the myth of democracia racial assures that the origins of embedded negative stereotypes remain both elusive and silent. In addition, my research data also confirm that my informants are aware of the myth of democracy racial, and contest its reality in private discourses.

My research data suggest that social groups (those that are based on race, gender, age, or socio-economic status) interact within the hegemony of culturally sanctioned silences in different ways, producing subtle ideological complexities that assist in perpetuating racial social norms and maintaining cultural silences about racial discrimination. For example, the working poor often blame themselves for their poverty; poor, darker-skinned, racially stigmatized working children argue the need to support their parents and to be "parents" to their younger siblings, while justifying the discrepancies of obvious social, racial, and class inequalities. Brazil's African descendants publicly deny, yet privately acknowledge, their own evidence of discrimination, while enduring social marginalization and exclusion. Protected by walls topped with embedded broken glass, "elites" (wealthy families, landed elites, and nouveau-riche) reside in communities that evade the existence of racism while supporting institutionalized practices of racial exclusion. These "elites" explain their fears of favelados ${ }^{5}$ and marginals in terms of social class and educational differences, effectively denying the daily reality of racism in their communities. Brazil's wide range of skin-color designations allows individuals to self-select their color identities based on location, context, gender, and social class, providing evasive strategies that partially mitigate the impact of racism, and in turn assist in perpetuating the myth of democracia racial. 
Institutional and social racism can, in part, be traced to the late 19th century national project of miscegenation and racial mixture known as democracia racial. The constructed ideology of democracia racial is not only embedded in patterns of social relations, but also in the practices of market economies, imbalanced educational systems, and exclusionary health care services. Current forms of racism and social inequality exist in modified but equally disturbing forms, and each was born from a definite political, historical, and economic context linked to the project of constructing a new Brazilian identity (Leal 1977; UNICEF 2004).

\section{Racial Formation Theory and the Cultural Practice of RACISM}

Omi and Winant (1994) outline a theory of race and racism that provides the basis for analysis of the symbolic power ${ }^{6}$ of historical racism in the lives of favela residents and university professors in this study. Omi and Winant argue that race is a complex of social meanings about the differences inherently found across human bodies. They argue that, while human physical characteristics (phenotypes) are biologically based, selection of these traits for use by social groups for racial identification is always socially and historically constructed. Since a biological basis for distinguishing visible human racial groups does not exist, and as anthropologist and human geneticist Alan Tempelton argues, "...the existence of human races cannot be demonstrated by using [the] quantitative threshold definition of race" (Goodman, Heath and Lindee 2003:240), it becomes necessary to understand how the concept of race continues to shape and structure social and cultural world views.

In addition, Omi and Winant argue that in order to understand the power that current prejudice and discrimination have on individual and collective consciousness, perceptions about "race" must be examined in relationship to historical, geo-political, and socio-cultural patterns (Omi and Winant 1994). The unique socio-historical processes that formed racial categories, and the institutions and governmental programs that absorbed, directed, and implemented racial practices, are key to understanding how race, social class, and discrimination have been expressed in Brazil. Currently, the same historical processes that produced Brazil's racial project continue in modified forms, thus perpetuating "...one of the world's most unequal distributions of income" (Skidmore 2004:133). The causes of Brazil's income inequality include cultural, racial, political, and economic factors that have remained resistant to democratic projects attempting to achieve a modicum of equality (Skidmore 2004). The conditions that created racialized identities and social inequalities are social productions that Marx stated long ago, and Brazilian Nunes Leal articulated in his critique of representative government in Brazil, "The conditions of production are at the same time the conditions of reproduction" (Marx 1977:711; Leal 1977). Social actors are engines of both production and reproduction, and as such are the only possible means for the reversal of "racialized social systems" (Weyland 2008).

Presented next is a brief discussion on race from a social science perspective, and a detailed discussion of the historical construction of Brazilian national 
racial identity. My ethnographic data demonstrate some of the ways in which racism in Brazil currently functions at both the macro and micro levels of everyday life, and is a legacy of the historical constructions of Brazil's racial project, democracia racial.

\section{Social ScienCe, RaCe, ANd Brazilian RaCial DEMocracy}

In 1998, the American Anthropological Association (AAA) adopted a draft statement on "race," declaring the concept of "race" as a cultural construct that,

...evolved as a worldview, a body of prejudgments that distorts our ideas about human differences and group behavior... [fusing] myths [about] human behavior and physical features together in the public mind. Such myths bear no relationship to the reality of human capabilities or behavior (AAA 1998).

While the AAA's statement on "race" conflates biological criterion for race into the paradigm of culture and ethnicity ${ }^{7}$, it does little to explain the meaning of race, its role in socio-cultural contexts, or the forces that cause and perpetuate it. Within the past 15 years, social scientists have been relatively silent on the topic of racial discrimination in Brazil and have done little to expose its historical origins. Since then, many social scientists (anthropologists and sociologists) have focused attention on Brazil's democracia racial. Thomas Skidmore's classic, Black into White: Race and Nationality in Brazilian Thought, demonstrated how the elite Brazilian intelligentsia developed misconceptions about race throughout the Old Republic, based upon notions of positivist white superiority embedded in social science theories (Skidmore 1995). Other scholars such as Twine (1998), Reichmann (1999), Burdick (1998), and Sheriff (2000), have provided important evidence of racism as experienced by Afro-Brazilians living within democracia racial.

Twine analyzes everyday discourses and practices of Afro-Brazilians that sustain and naturalize white supremacy, while Reichmann exposes the structural components of contemporary racial dynamics and the economic, educational, and social impact of these on Afro-Brazilians. The efforts of the movimento Negro activists are explored by Burdick, whose work examines racism in tandem with popular religion, Afro-Brazilian activism, the Brazilian nation-state's resistance to activism, and the cultural politics of gender. Sheriff's work plumbed the depths of Afro-Brazilian consciousness and explored domains of cultural silences among Brazilian favaledos in Rio de Janeiro; her work ethnographically demonstrates the reality of everyday racism experienced by Afro-Brazilians. My own work with Brazilian street-and-working children (the majority of whom are darker-skinned African descendents) demonstrates how poverty, racism, and cultural constructions of childhood impact many children of color (Mikulak 2002; Mikulak 2007a; Mikulak 2007b).

Over the past 15 to 20 years, several government agencies have compiled data on social, economic, and educational categories across ethnic and gender lines, thus providing more reliable information on racial inequalities from which a new body of literature on Brazilian racism has emerged. According to sociologist Marcelo Paixão at the Federal University of Rio de Janeiro, such data has 
contributed to the deconstruction of the myth of democracia racial, resulting in an ever-increasing amount of Brazilian social science data on racial inequality (Paixão 2004:744). ${ }^{8}$

In spite of the growing evidence of racism in Brazil, few social scientists have explored the embedded racial meanings associated with skin-color. In Brazil, skin-color identification systems are seemingly embodied representations of 19th century racist "scientific" notions about Africa and her people. Such "scientific notions" supported the agenda of Manifest Destiny and guided the Western world's policies on colonization, slavery, and modernization, crafting deep social and cultural beliefs about racial and ethnic identity that have become part of the structure of everyday life in Brazil (Rodriguez 1992; Segato 1998; Sheriff 1997). These structural influences exist in regional linguistic racial and ethnic stereotypes of people that include such terms as caboclos, sertanejos, and caipiras. ${ }^{.}$Currently, Brazilian structural social inequality is broadly defined by the continued perpetuation of stereotypes developed by 19th century European scientific notions of racial categories that reflect democracia racial through the use of skin color terms, regional demographics, and phenotypical descriptors of personal physical attributes.

Robin Wright, at the Universidade Estadual de Campinas, critiques Ribeiro (1922 - 1997) who is considered by some Brazilianists to be Brazil's "father of anthropology":

...Ribeiro presents his paradoxical vision of Brazil as a "homogeneous and unified" people, yet [Brazil is] a house of cards, a barrel of gunpowder riddled with internal social contradictions and explosive racial and social tensions which, in fact, are becoming ever more evident as time goes on (Wright 2002:703).

Ribeiro (who was Minister of Education under President Goulart, and held a variety of other educational and political posts) was an influential Brazilian anthropologist, author, and politician whose notions of Latin American identity as homogeneous, uni-ethnic, and unified perpetuated Brazil's myth of a democracy racial. Ribeiro's historical account of the evolution of the "Brazilian" people is based on notions of cultural evolution whose roots spring from the late 19th century pseudo-science of Social Darwinism (Ribeiro 2000). The tensions described by Wright demonstrate the power that politicians such as Ribeiro can use to reinforce national histories that attempt to create false notions of racial uniformity. While Ribeiro sought to understand the racial tensions, complexities, and contradictions within Brazilian society, he also perpetuated national ideologies of ethnic unity that further solidified the racial tensions he sought to understand.

Anthropologist Carole Nagengast argues that the crisis of the contemporary nation-state lies in their ability to create and maintain a consensus among its citizens "...about what is and what is not legitimate. When consensus fails, ethnic or political opposition, which is otherwise suppressed or subtle, becomes overt; the state, of course, cannot allow this to happen" (Nagengast 1994: 109110). Brazil's racial project exemplifies the force and longevity of the power of the nation-state's role in the creation of democracia racial, where attempts at 
"Black is Beautiful" movements were deemed "un-Brazilian;" Skidmore notes the movement itself was "...branded by many whites as a foreign import" (Skidmore 1983:108). Some social scientists argue that such denials of the Black Movement illustrate the degree to which Brazilian Blacks are culturally alienated (Fontaine 1985; Hale 1997; Healey 2003). "Black is Beautiful" movements in Brazil have struggled mightily to politicize the use of the term Negro as a positive indicator of Black Pride with little success (Baran 2007).

Strategies to deny the legitimacy of "black pride" social movements in Brazil have succeeded for several reasons:

- The myth of democracia racial effectively convinces Brazilians of all phenotypes and color-tonalities that race is not an issue, and many who experience racism deny its existence.

- Little national, state, and municipal attention via local media outlets has been paid to racism as a social experience. Open public discourse about the popular beliefs of what "race" is, and how race has been historically constructed and reconstructed is largely discouraged and ignored in Brazilian media and educational textbooks.

- Individuals experiencing racism have little to no knowledge and/or access to recourses to take action against racial discrimination.

- National laws that legally define "racial" differences do not exist (as in the U.S.'s "Jim Crow" or South Africa's apartheid), and as such, the experience and topic of racism is not "real" to Brazilians of all colors and phenotypes.

Thus, for people to talk about and struggle against racial discrimination, they must know that it exists, and be able to validate its existence through social discourse and participation in local and national organizations that combat racism.

While I emphasize that the denial of racism is a tool used by both oppressors and the oppressed to maintain a racial status-quo (hegemony), I do not wish to victimize the victims of racial discrimination. The nature and function of hegemony is such that not only the "powerful" reinforce discourses about racism, but also the racially oppressed often insist that they are not oppressed, frequently denying experiences of discrimination in their lives (de Paula Souza 2005). The works discussed above substantiate evidence of racism in Brazil, but few bring together the historical antecedents of science, history, anthropology, and ethnographic research under a single tome to examine the powerful effects that historical, political, and cultural constructions of "race" have on contemporary life in Brazil.

\section{The Historical Construction of Democracia RaCial:

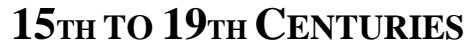

In the late 15th century, the epoch of European colonization brought about the eventual integration of global economics. The practice of slavery and its brutal exploitation of human labor provided fertile ground for the propagation and exploitation of race, and the burgeoning scientific revolution, beginning in the 
Enlightenment, added validity and justification for the subjugation of peoples-ofcolor (Bonilla-Silva 1999; Skidmore 1995; Winant 2000).

The effects of 300 years of Portuguese colonization assured the continuation of Brazil's slave economy long after the end of the slave trade in 1850. As a result of competing tensions between military and political elites and increasing international disapproval of Brazil's continued practice of slavery, abolition was not achieved until 1888 (Skidmore 1999). Fearing that abolition of slavery, and the social system of master-slave relations would cause the loss of personal wealth and disrupt long-established hierarchical social structures imported from Portugal's patrimonial and "personalistic" 10 (Skidmore 2004) social system, Brazil's "landed-elites" worked to preserve those master-slave relations, thus molding a national identity that disguised structural racism with enduring success (Skidmore 2004; Leal 1977; Prado 1966).11 During slavery, and after its abolition, ideological discussions about Brazilian identity were influenced and informed by imported 19th century science and Social Darwinist anthropological thought "...offer[ing] scientific validation to proponents of racial hierarchies," supporting the denigration of people of color and the racial superiority of whites (Baker 1998:3, 35). The paradox of democracia racial lies in a contradictory premise: “...acceptan[ce] of the existence of innate human differences while praising the practice of racial blending" (miscegenation) (Schwarcz 1999:16).

Changing the Negro and Indian into a "whiter" (mestiço) population required justifying the continuation of miscegenation, blending not only skin-color, but also colonial "master-slave" relations, post-colonial "scientific" paradigms about race, and enforcing Brazil's "personalistic" social system, even among its most "peripheralized" citizens.

Near the end of the 19th century, Brazil's political rhetoric about development and progress promoted the need to construct a new identity for Brazil's racially mixed population. By the end of the 19th century, Brazil had largely accepted the French sociology of de Gobineau's "On the Inequality of the Races," and Moreau's "Treaties on Physical, Intellectual, and Moral Degenerations," where Gobineau argued that "pure" conquering races (Western Europeans) degenerate after reproducing offspring with "inferior" races (Indigenous and African peoples), and Moreau defined degeneration as the hereditary transmission of weak traits from inferior to superior races (de Gobineau 1856; Borges1993). Due to the mixture of three "distinct races" (Portuguese, Indigenous, and African, the latter two of which were viewed as degenerate), Brazil's population resulted in the miscegenated mulatto (mestiço), which created both the problem and the solution in the construction of a new national identity. A solution to the problem of Gobineau's and Moreau's theories of degeneration as a result of interracial mixing was achieved by rejecting the fatalistic assumptions of their theories and embracing instead the notion that racial mixing could elevate and whiten the population (Skidmore 1995).

Historically, constructions about "race" in Brazil were primarily "biologized" according to phenotypical differences (not on rigid descent rules, as in the United States), thus rendering racial identification to be dependent on the meaning of phenotypes (including skin-color tonalities), and secondarily, on socioeconomic relations. While skin-color was initially important and viewed as a racial 
signifier, it became secondary to physical appearance. In today's Brazil, skincolor tonalities can be "lightened." Once an individual who previously identified as "Negro" achieves some economic success and status, s/he can "re-invent" her/himself as "brown" (de Carvalho et. al 2004). Brazil's current colorization of skin according to color gradients, social capital, and economic position is a racist system that expands into all social spaces (Telles 1995; 2004). However, while money and social status can have the effect of "whitening" someone, it is difficult if not impossible for those persons on the "darkest" end of the skin-color spectrum (who also possess certain "African" phenotypes) to achieve upward social and economic mobility (Bonilla-Silva 2010: 181-198).

\section{Brazil's 20th Century Colonial and Post-Colonial Paradigms of RaCe}

Due to its mestiço population, the Western world by 1900 viewed Brazil as a "tropical slum." Grappling with a declining labor force, an increased population of freed slaves in need of paid labor, and the preservation of a caste system based on colonial patron-client relations from the latifundistas landed-elite, those crafting the "new" Brazil used the revisionist racist theories to support the growing labor needs of the state and to legitimize the bourgeoning mestiço population (Schwarcz 1999). Brazil opened its doors to white immigrants from Italy and Germany, beginning the nation's policy of "Whitening" the mestiço population.

Four 19th century European racist social science theories (polygenesis, monogenesis, classical cultural evolutionism, and social Darwinism) 12 influenced Brazil's 20th century political forums, and assisted in the construction of racial theories about the uniquely Brazilian mestiço. A determinist perspective about race and social evolution was combined with miscegenation into a workable pseudo-scientific perspective that validated the Brazilian mestiço, while maintaining the superiority of light-skinned lberians from Portugal. By equating social differences (wealthy vs. poor and educated vs. illiterate) with racial variations (phenotypical appearances that include skin-color), and declaring the extinction of the "pure" Indian or "pure" African, Brazil carved out the new national identity of the Moreno/a and achieved domination over indigenous peoples, freed slaves, and darker-skinned African peoples. Nina Rodrigues (1862-1906), the first Brazilian researcher to study the African influence on Brazilian society, argued that darker mestiços could only be allowed to possess (by law) "attenuated responsibilities," since their regressive racial traits rendered them irresponsibly "childlike" (Rodrigues 1976). The mulatto or moreno body was successfully transformed into the "real" Brazilian and those with darker skin-colors and African phenotypes were hegemonically constructed as perpetually marginalized and socially stigmatized (Gould 1996; Schwarcz 1999; Skidmore 1995).

\section{STRUCTURAL InSTITUTIONAL RACISM}

The new national identity used scientific notions of race to craft social policies and apply them to medicine, education and religion in the hopes of leading Brazil to new heights of civilization and modernization (Rizzini 1994:83-10; Schwarcz 
1999:29-35). For example, identification of degenerate traits associated with Afro-Brazilians often relied upon

...aesthetic criteria to evaluate individuals and peoples. Medical analysis looked for signs ('stigmata') of degeneration in the face and body of a patient: protruding jaws, beetling brows, dark skin colour. Not all of these signs were inborn...The nineteenth-century sciences of physiognomy and phrenology, though in decline, provided the link between psychiatry, anthropology, and the visual arts. In painting and caricature, ape-like or animal facial types became conventional signs of social menace and bestial traits (Borges 1993:238).

Political rhetoric produced debates on and about inferior and superior races, and theories of degeneracy were debated by politicians, doctors, and educators in government chambers and halls of justice where social policies were crafted. Institutions such as The Assistance Service to Minors (SAM, created in 1941), and the National Foundation for the Welfare of Minors (FUNABEM, established during the Military Regime in the early 1960s to replace SAM), drew from the rhetoric of Western European pseudo-scientific doctrines of racial hierarchies. 13 During Brazil's transition to democracy in the mid-to-late 1980s, hundreds of Non-Governmental Organizations (NGOs) were formed to uphold basic human rights for the marginalized and economically poor. Nonetheless, extreme poverty in Brazil and racial discrimination has remained resistant to the efforts of those NGOs to mitigate Brazil's extreme social, economic, and racial inequality.

Brazil's new identity resulted in the national policy of "whitening." Western European immigrants, particularly from Italy and Germany, were welcomed because their paid labor was desired over that of blacks (pardos, pretos and Negros), and their "whiteness" would, through the process of miscegenation, result in building a lighter skinned mulatto population. The mulatto was decreed to possess a stronger intellect, thus rescuing them from the denigration and marginalization associated with black Africans, who continued to be constructed as inferior and primitive (based upon European colonial social constructions about the inferiority of phenotypes associated with African descendents) (Skidmore 1995).

\section{Pejorative Scientific Constructions of Phenotypical TRAITS}

According to some scholars, medieval perceptions of "blacks" were not generally pejorative (Fernandez-Armesto 1987; Jahoda 1999; Tytler 1982); however, as European (Portuguese) exploration moved southward, racial antagonism spread, casting black Africans in crude terms that included ridiculing their sexuality as well as their humanness. Jahoda's work in psychology and anthropology provides an intriguing analysis of how deeply rooted racial perceptions associate blackness with darkness, evil, the devil, and all that is primitive (Jahoda 1999:26-28). In my research, participants drew from highly pejorative symbolic meanings of Afro-Brazilian phenotypical appearances and 
skin-color tonalities when discussing racism in Brazil, reflecting Jahoda's analysis of embedded symbolic notions about African peoples.

With the intensification of colonial exploration along the coast of West Africa in 1442, the first African slaves were brought back to Portugal (Jahoda 1999) where they were commonly cast in pejorative terms. By the 19th century, historians tended to contextualize black Africans in the following manner: "On the continent of Africa was another race, savage in their natural state, which would domesticate like animals" (Froude 1895:49-50). Other constructed assumptions by early explorers and historians about African people included observations of their lack of reason, dexterity, and refinement in arts and material culture. Such assumptions, drawn from the medieval notion of the Great Chain of Being (Lovejoy 1936), resulted in the scientific racism of Carl Linneaus, Lamarckian evolutionary theories, and naturalists whose works hypothesized biological comparisons between humans and apes, particularly in reference to their ability to inter-breed. Even as late as 1826, naturalist Jules Virey stated:

One could presume that hairy savages are half-breeds of apes and women... One knows nothing about what kind of love goes on in these ancient forests, where the heat of the climate, the brutal life of the inhabitants, the solitude and the delirium of passion, without law, religion, morals, can lead to daring everything; and these degraded beings, these monsters half-way between humans and apes... will long remain unknown to us (Jahoda 1999:45-46).

In Races and Peoples (published in 1890), archeologist and ethnographer Daniel Brinton argued that mental and physical characteristics were correlated with racial differences, stating that the "African negro [is] midway between the Orangutan and the European white...the African black...presents many peculiarities which are termed 'pithecoid' or ape-like" (Brinton 1890:276-277). While John Wesley Powell (who was a supporter and champion of Native American peoples) distanced himself from strict evolutionists such as Brinton, he supported theories of the racial superiority of whites. In an 1888 article Powell stated:

The human race has been segregated from the tribes of beasts by the gradual acquisition of these humanities, namely: by the invention of arts; by the establishment of institutions; by the growth of languages; by the formation of opinions and by the evolution of reason...the road by which man has traveled away from purely animal life must be very long; but this long way has its land-marks, so that it can be divided into parts. There are stages of human culture. The three grand stages have been denominated Savagery, Barbarism, and Civilization (Powell 1888:8).

As mentioned above, influences from French historians and philosophers include, but are not limited to, the writings of de Gobineau (1843-1859), who argued for the "uncivilizability" of black and mixed-raced peoples, and Le Bon's (1894) argument for the existence of distinct species of humans based on anatomical differences of skin color and cranium size. 
Finally, Swiss naturalist Louis Agassiz who traveled in Brazil, had a profound influence on the development of "scientific racism" in Europe and the Americas and ultimately, Brazil. Agassiz was perhaps the ultimate polygenist of the 19th century. In writing to his mother about his first actual contact with "Negroes" in the United States, he stated:

As much as I try to feel pity at the sight of this degraded and degenerate race... it is impossible for me to repress the feeling that they are not of the same blood as us. Seeing their black faces with their fat lips and their grimacing teeth, the wool on the heads, their bent knees, their elongated hands, their large curved fingernails and...the livid color of their palms... what unhappiness for the white race to have tied its existence ...to that of the negroes! (Menand 2001:112).

The impact of "scientific racism" on African and Indigenous Peoples throughout the colonized Americas was profound, not only in terms of horrific physical suffering, but also in terms of denigrating cultural constructions that cast them as less than human. Such constructed ideologies, born during the rise of European expansion into the Western Hemisphere, are embedded into the socio-cultural fabric of Brazilian contemporary life. The development of the African slave trade and the practice of the extermination of Indigenous Peoples is as much a part of the silenced, yet tacitly accepted assumptions of the racial inferiority of Africans and Indigenous Peoples as is the assumed consensus of the superiority of Europeans as the most advanced "race" of humans.

An examination of current skin-color identification and demographic information on poverty and illiteracy based on Brazilian census data follows; then a discussion of my findings from focus groups and individual interviews illustrates the link between current racial discrimination and the socio-historic legacy of Western European 18th and 19th century pseudo-scientific racism to Brazil's racial project, democracia racial.

\section{RaCe ANd Brazilian Census Data}

Outside of Africa, Brazil currently has the largest African-descendent population with a non-white national demographic estimated to be between 45 percent to 70 percent, as well as possessing one of the most unequal economic distribution systems in the world, with a Gini Coefficient (in February of 2009) of 57.1 (de Campos Meirelles 2009).14 The 2002 Brazilian national census provided clear evidence of profound racial inequality: For example, pretos (black) and morenos (brown), 15 years and older, have more than twice the illiteracy rate of broncos (whites), while functional illiteracy 15 is greater among pretos and morenos than in the white population (do Valle Silva, Nelson, and Hasenbalg 2000; World Bank 2004: Amaral 2006). In 2004, the Economic and Social Council of UNICEF stated that "Afro-descendent children are twice as likely [in Brazil] to be out of school, with the average number of school years dropping from 4.2 for white children, to 3.3 for afro-descendent children, to 2.5 for indigenous children (UNICEF 2004:2).

Racial discrepancies are evident when comparing data on education levels: Ninety-eight percent of professors (with a master's degree or PhD) are white, 
while 48 percent (or more) of the population is pardo or preto, but only 14 percent of university students are darker-skinned Afro-Brazilians (Ramos 2006; Morley 2005). In addition, darker-skinned Afro-Brazilian descendents earn only half as much as their white co-workers, while 21.8 percent of Negros are classified as indigent, as compared to 8.4 percent of whites (de Paula Souza 2005:9). According to Paixão, disaggregated data for African descendants and whites reveal the severity of racial inequality in Brazil compared to other countries, including Africa. Paixão states, "The black population in Brazil is still characterized by the absence of collective social rights and by the wide gap separating its living standards from those of the Brazilian European descendant population" (Paixão 2004:743).

A chronological review of Brazil's national census data-collection methods on race reveals clear inconsistencies: In the 1950s, census data on race were collected on only four skin-color categories (black, white, yellow, and brown); in 1960, an additional category, "indigenous," was added. Although the 1960 census was never fully published, two of the categories (brown and indigenous), were collapsed into the category of brown (pardo). From 1970 to 1979 during the Military Regime, race data were not included as a part of the national census. In 1980, race was re-introduced into the census, using the five categories used in 1960 (de Carvalho et.al 2004:333).

While the census gathers data on four skin color terms and one indigenous category, Brazilians have developed a plethora of additional skin-color designations that are both context- and personal relationship-dependent. Rothblatt's (1998) study on the use of race-based addressee terms demonstrates how important social context is when race is used in public conversation. She argues that negatively valued linguistic terms (such as "negão" for blackness) contain both hostile and endearing meanings, such that meaning is coded for "degrees-of-intimacy." While Rothblatt's argument demonstrates the complexity of the meanings of skin-color terms in relationship to social context, it does not account for the use of negative, racially pejorative terms that have been reconstructed as terms-of-endearment used by everyday Brazilians of all skincolor tonalities.

Based on recent social science research about race in Brazil, the government, in 2004 quietly issued an 87-page document, "Political Correctness and Human Rights," which listed 96 words and phrases it hopes will eventually become unacceptable. (Approximately 17 of those words and phrases refer to race). In the May 17, 2005 issue of the Christian Science Monitor, Correspondent Andrew Downie states that the assistant secretary for the government's Promotion of Racial Equality, Douglas Souza suggests that "Racism in Brazil exists though hidden interpersonal relationships... There are no racist laws, but there is a culture of racism and the instruments of that racism here are words" (Downie 2005:1-2). Due to public disapproval, the government quickly retracted the document which declared that such terms were offensive to some people while leaders of Brazil's Black Consciousness movement argued that the document was necessary. Ivanir dos Santos, one of the most outspoken Black leaders in Rio de Janeiro, stated: "One of the principal characteristics of Brazilian racism is that we don't talk about it. Withdrawing it [the 2004 document] is a mistake...People tried to disqualify [the document] because it touches on words 
that are racist and that are used as a matter of course" (Downie 2005:1-2).

Similar to other public discourses about race, census data are contextdependent and linked to the government's unofficial policy of whitening. For example, I refer again to the census data collected between 1950 and 1980, which reveal a decrease of 38 percent in the preto (black) skin-color category, and an increase of 34 percent in the pardo (brown) category. Researchers suggest that, because these two percentages are relatively equal, this may be an indication of persons who self-identified as preto in 1950 consciously "reclassifying" themselves as pardo in 1980. A similar pattern was discovered for the national census between 1980 and 1990 (de Carvalho et al. 2004; Winant 2000).

My data illustrate how colonial constructions about African phenotypes and early 20th century national "whitening policies" continue to construct and define (in a negative way) Afro-Brazilians as they self-identify along Brazil's skin-color spectrum.

\section{METHODOLOGY: Focus GrouP AND INDIVIDUAL INTERVIEW DATA}

In 2004, my field assistant, Clemenson Campos da Cunha, and I organized focus groups that consisted of adolescents in public schools, adult favela residents (favelados), and individual interviews with professors who serve in public and private universities in Brazil's third largest city, Belo Horizonte (IBGE 2007): The 36 participants consisted of:

- Three adolescent focus-groups: 25 participants total (14 females, and 11 males, all with a median age of 13 , were recruited by their schools and registered with administrators; all participants were public school students living in selected favelas with high levels of poverty).

- One adult favela focus-group: five participants (4 females and 1 male).

- Individual interviews: six participants (3 female professors, and 3 male professors, representing both federal and private universities).

All interviews were arranged by my field assistant; focus groups and interviews were thematically organized to address the following questions:

- What is race?

- What are the skin-color terms that you use and hear other people

- use?

- What is your skin-color?

- What is the meaning of your skin-color?

- Why do you self-identify with this skin color?

- What are your definitions of race?

- What is your definition of racism?

- How have you experienced racism?

- How do you recognize racism? 
- What is the meaning of the term Negro?

- What is the meaning of the term preto?

From darkest to lightest, skin-color identification terms were developed and self-selected by focus group participants and by participants in individual interviews (i.e., participants were not given a prepared list of racial terms from which they could "choose" a skin color for themselves). As part of skin-color terms, the symbolic meanings of those terms were also defined by focus group participants and individual interviewees:

1. Preta: Black. A pejorative term, except for those few who were politicized

2. Negra: Dark, dark brown or black with tonalities of brown; also signifies phenotypes associated with African descent (indicating ethnicity and dark skin color)

3. Parda: Very brown (verging on black), considered a pejorative term, but preferred to the term preta

4. Morena Escura: Medium to dark brown

5. Mulatta: Dark tan to dark brown (a sexualized term - particularly

for women of dark to very dark skin color), considered a

pejorative term

6. Morena: Light brown

7. Morena Clara: Very light color

8. Clara: Light cream color

9. Branca: White

\section{DISCUSSION OF FINDINGS}

Of the 25 adolescent participants, the most frequently self-selected skin color was moreno/a (12 of 25 , or $48 \% \square$ see Table 1 ), while the remaining eight other skin-colors where relatively evenly self-selected (see Graph 1).

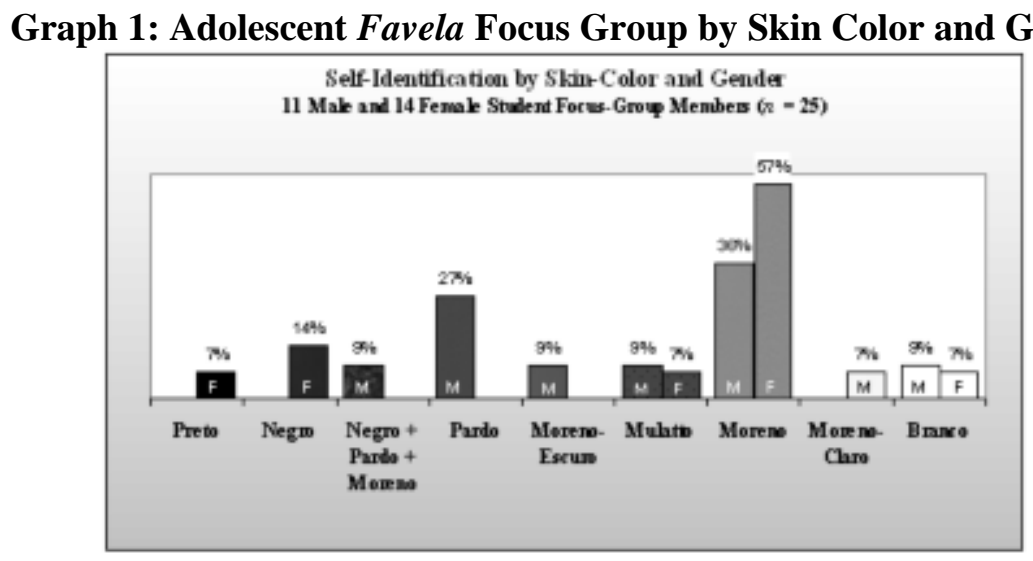

For the adult favela focus-group participants (four females and one male, $\boldsymbol{n}=5$ ), two females self-identified as negra, one female self-identified as morena, one female self-identified as clara, and the male self-identified with two terms, negro-preto. 
Interviews with university and school professors (three females and three males, $\boldsymbol{n}=6$ ) identified only one skin-color tonality (moreno/a), with light and dark "modifiers," from the darkest to lightest colors: morena escura, morena, and morena clara: four self-identified as moreno/a, one self-identified as moreno-escuro, and one self-identified as morena-clara.

Table 1: All Participants by Skin-Color and Gender $(n=36)$

\begin{tabular}{|c|c|c|c|c|c|c|c|c|c|c|c|}
\hline \multirow{2}{*}{$\begin{array}{l}\text { Self-Lentified Slin Cabr } \\
\text { (Darkest to Lightest) }\end{array}$} & \multicolumn{6}{|c|}{ Respondent Groups } & \multirow{2}{*}{$\underset{\text { M }}{\text { Tatal }}$} & \multirow{2}{*}{$\begin{array}{c}\text { Total } \\
\text { F }\end{array}$} & \multirow{2}{*}{$\begin{array}{l}\text { Fa of } \\
\text { all M }\end{array}$} & \multirow{2}{*}{$\begin{array}{l}\text { Quaf } \\
\text { allF }\end{array}$} & \multirow{2}{*}{$\begin{array}{l}\text { Qbof } \\
M \& F\end{array}$} \\
\hline & \multicolumn{2}{|c|}{ Adolesents } & \multicolumn{2}{|c|}{ Favelades } & \multicolumn{2}{|c|}{ Profescans } & & & & & \\
\hline Negn + Preto & & & 1 & & & & 1 & & 6.7 & & 28.8 \\
\hline Prete & & 1 & & & & & & 1 & & 48 & 2.8 \\
\hline Negn & & 2 & & 2 & & & & 4 & & 190 & III \\
\hline Negre + Parde + Marene & 1 & & & & & & 1 & & 6.7 & & 2.8 \\
\hline Pante & 3 & & & & & & 3 & & 211 & & 8.3 \\
\hline Morena-Escuro & I & & & & & 1 & 1 & 1 & 6.7 & 48 & 56 \\
\hline Mulatio & 1 & 1 & & & & & 1 & I & 6.7 & 4.8 & 56 \\
\hline Morema & 4 & e & & 1 & 2 & 2 & 6 & 11 & 400 & 52.4 & 472 \\
\hline Morem-Claro & & 1 & & & 1 & & 1 & $\mathrm{I}$ & 6.7 & 48 & $\$ 6$ \\
\hline Che & & & & 1 & & & & 1 & & 48 & 28 \\
\hline Brance & 1 & 1 & & & & & 1 & 1 & 6.7 & 48 & 56 \\
\hline Gender and Group Sul-Totak & 11 & 14 & 1 & 4 & 3 & 3 & 15 & 21 & 1000 & 1000 & 1000 \\
\hline Group Sth-Totak & 2 & & & & & & 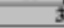 & & & & \\
\hline
\end{tabular}

Among all 36 participants, Negro was preferred over the term preto (11.1 percent self-identified as Negro, and 2.8 percent self-identified as preto), while the terms claro and bronco were chosen 2.8 percent and 5.6 percent of the time, respectively. All skin color terms are presented in masculine form (see Table 1).

\section{PRETO VS. NEGRo - INDIVIDUAL INTERVIEWS AND AdULT FocUS Group PARTICIPANTS}

When adult favela focus group participants were asked if they preferred the term preto or Negro, they frequently used both terms synonymously, yet when they distinguished between them, their distinctions were based upon degrees of skin color darkness. In other words, a dichotomous distinction between preto or Negro was not a viable choice, since multiple color gradations are used to mitigate the extremes between these two terms. For example, the following male adult favelado (who self-identified as preto and Negro) stated:

....preto and Negro are the same words...only Negro is a moreno that is a little lighter, but Negro and preto are the same thing... [but] preto is a very pejorative term...so, if someone calls me preto, I say that I'm not preto, I'm Negro.

In this example, the adult male favela resident, stated that the term preto is seen as derogatory. The same participant also stated that if a close friend or relative referred to him as pretinho (little black - an apelido or nickname), such a term would not be offensive, depending upon whom is speaking, and the shared understanding of the type of relationship existing between the addressee and the addressor. This confirms Rothblatt's work on address terms. When asked why the term pretinho would not be offensive when used by a close friend or intimate, he replied, "You know, a friend calls you a "pretinho," or "negão"“ and it's like saying 'hey man, you're dark, but it's OK, I like you anyway." This explanation implies that friendships can mitigate negative social stereotypes, and that racialized apelidos provide a kind of social bond, at least for this participant. Participants told me that referring to oneself as preto is generally understood to be self-demeaning and brings with it social, cultural, and historical meanings 
most Brazilian's avoid unless the intent is to demean or otherwise inflict emotional distress or signify a level of intimacy that inverts abusive terms into acts of affection. For example, a Moreno male (the director of a public school and a professor of mathematics), articulated metaphors of "preto-ness" in rather strident terms, referring to preto as that which:

.... is associated to bad things, to what may be forgotten - preto is dirty - it's different from saying Negro, you say 'preto' and you are meaning something that is of little importance, that is pejorative, less intelligent, poor, ugly - well, you know, the mouth, the nose, the hair.

An adult Negra female favela resident said, "I think that preta is pejorative I think that 'preta' is too strong, because preta is really something preta - without light, full of darkness." A male moreno history professor from the Federal University of Belo Horizonte presented this meaning of Negro:

Preto is the Negro color, right? Preto, preto - I think that in history, in the language's past - I think that the idea of darkness, of being dark, everything that is dark reminds us of the idea of backwardness. Hell is Negro - I think that we Brazilians have this misconception, very disguised, very hidden, about the Negro being underdeveloped, less intelligent.

A female morena professor from a state school who was quoted at the beginning of this article expressed colonial connotations about the negative meanings of dark skin:

...There are many reasons-the slavery period in Brazil, because of what the Negro brings with him from such a time-a past of misery, of suffering, of being chased, of being imprisoned-The Negro brings everything related to poverty, to being a servant,- -who will ever be proud of poverty, of being caught, of being a servant...because the idea of being Negro is the question of being a servant, a subordinate. What is the image of the Negro? A beast-ofburden! Who will ever be proud of being a beast of burden? I mean, the Brazilian consciousness about who the Negro is, is really what needs to be changed.

Beliefs about the inferiority of darker to darkest skin-color terms and the negative stigmas attached to them are evident in the statements of the above participants who represent a spectrum of social positions, social class, and selfidentified skin colors. Demographically, their perceptions and understandings about the symbolic meanings attached to the use of the term preto are fairly consistent and could imply uniformity about the racialized meanings of various skin-color terms across socio-economic and other demographic lines.

While participants frequently conflated the term preto with the term Negro, Negro was characterized as being less pejorative, but my informants seemed conflicted by the use of the term. To them, the term Negro implies darker skincolor tonalities along the skin-color spectrum that they use, but it is preferred 
over the term preto when identifying as a darker-skinned Afro-Brazilian because it is "lighter" than preto. Historically, Negro was the racial term used when referring to African slaves (Baran 2007), and interestingly, my participants referred to the term Negro as implying African ethnicity. My participants also associated preto with the darkest of skin-color tonalities, which seemed to imply a lack of racial mixture. In this sense, the term preto is an exclusionary term that identifies an individual as being apart from the national identity of Moreno, as constructed by Brazil's racial project. This exclusionary nature of dichotomous skin-color terms also helps explain why little popular resistance to Brazil's practice of racial discrimination exists and why Black Afro-Brazilian movements have not increased in popularity.

One adult favela focus group participant stated, "If you say Negro, you're talking about the race, but if you say preto, that dark skinned hue, you're offending a lot more than if you say Negro." However, another adult favela participant argued that while Negro is preferable to the term preto, to be called Negro is still offensive:

...It started with slavery, first enslaving the Indians and then bringing in the Africans, the Negro, and this comes from generation to generation, because when you say Negro it is an offense; it is about a person that was thrown into society; it's like falling from the sky out of nowhere.

While the term Negro was the least offensive to the favelados, it signified a "race" without a legitimate heritage of historical pride. To the Brazilian political elites who crafted the racial project of democracia racial, the essence of Africa as a continent and as peoples lacked historical legitimacy in terms of enlightenment ideologies of progress and development. Brazil's racial project of miscegenation is embodied and expressed in many of my informants' statements as a sense of both shame about their racial past and inherited skin color, and indignation at the continued expression of racial and social marginalization. Because of the still-popular notion of democrica racial and a slow, but growing awareness of racial inequality, many informants found our discussions on race, skin-color, and racism to be difficult. At present, there is little recourse for economically poor individuals who experience racism due to skin-color and/or phonotypical stereotypes. While Brazil's new constitution provides for legal recourse, few individuals have access or the resources to take their cases to court. Not surprisingly, moreno/a was the most often self-selected skin-color by all participants (47.2 percent). Moreno/a is most commonly used since it is a "neutral" term that refers to almost any combination of phonotypical features; it refers to a blending of skin colors reflecting the nation-state's racial project of Brazilian identity: a continuum of light-brown to darker-brown skin color with physical features that do not represent African phenotypes. A female favela student was one of the few participants who self-identified as Negra. She spoke of her understanding about the lack of racial consciousness in Brazil when she stated, "In Brazil, there is no consciousness about racism - we are still extremely backward in this - we don't have a mature consciousness of what it is to be Negro." This participant was the only one who expressed pride in being Negra, which she attributed to the mentorship of a teacher in her school. 


\section{EduCATION, GENDER, Job MARKET Discrimination}

Along with the national policy of whitening, educational practices in Brazil reflect the nation-state's racial project of democracia racial in deep structural ways, including the dichotomy of public vs. private primary and secondary schools, and public vs. private universities. The use of the vestibular (university entrance exam) effectively "filters-out" the economically poor who are most often Afro-Brazilian public school students who apply to federal universities (the best research schools), enrolling only those with high vestibular scores who can afford specialized courses preparing them to take the exam.16 Racial tensions within the market place and in educational settings were readily evident among my informants (particularly among darker-skinned Afro-Brazilian females) when we discussed gender and race.

My findings correspond to Sansone's research on constructions of race, ethnicity, and identity among young, poor, Afro-Brazilian youth in Bahia, who demonstrated awareness that their prospects for employment in the formal economy were slim to non-existent (Sansone 2003:35-37). Despite repeated assertions of their belief in Brazil's democracia racial, favela adolescents in my study were also keenly aware that skin color and phenotypical attributes adversely affect their prospects in the market place. Baran's (2007) work in Southern Bahia among adolescent high-school girls demonstrates how skin-color terms are frequently manipulated by job applicants as they vied for jobs. In Baran's study, competing for jobs meant that women often worked diligently to straighten their cabelo duro (hard or wiry hair), and usually spent up to one-third of their monthly salaries in local salons in order to achieve a physical transformation that would hopefully assist them in securing a job. Adolescents in my focus groups also discussed the negatively constructed gendered stereotypes attached to Afro-Brazilian females. A morena favela female adolescent described the experience of a friend who was passed over for a teaching job because she was perceived as a Negra:

And they looked at her from top to bottom and said she was Negra. And then they picked the light-skinned girl, all blondish and pretty, even though she didn't have the same qualifications the Negra one had, but they picked her because she was light-colored.

A branca female favela student described how both the media and the job market negatively "profiles" dark-skinned women's intellectual "disabilities" stating, "The Negra woman - you never see a Negra woman doctor, all you see is Negra janitor, Negra maids, Negra farm workers." A Negra female professor in a public school provided her personal experience of "racial profiling" in the job market, referring to newspaper job application ads calling for "young women with good looks." When she and a "white" friend applied for the same job, the Negra professor was passed over and told that "... Negras couldn't work there... when job advertisements say 'good looks,' they're talking about your skin color" and African phenotypes. The same women told me that such advertisements were actually "codes" for saying, "no blacks need apply." A morena female adolescent described being taught negative stereotypes about Africa and Negros in school: 
We saw and learned that the Africans were the personification of suffering, a people with no culture that can't reach anywhere; they never leave that place, always having the same lame life.

In discussing the history of economic and educational discrimination, a morena female professor of sociology and director of a public school stated that the current age at which poor children (usually of darker skin color) begin working on the streets in today's informal economy is between 7 to 8 years of age (a legacy from slavery). She continued by clarifying how inferior educational opportunities for Negros continue to be prevalent: "There isn't a single one [dark-skinned Afro-Brazilian] that isn't a slave-descendent that has not suffered from the issues of educational and economic racism." Finally, a moreno male director of a public school described educational racism this way:

Public education is awful and serves mostly Negros - we are producing a large number of people that will never have real jobs Brazil is like India, with a caste system, the doctor's son will become a doctor, engineer, lawyer - and downward it goes.

\section{Symbolic Meanings of Skin Color Gradients}

A Negra female student stated that the term preto implies a stain against basic humanness in Brazil. "In the books that I have read - death is always associated with preto [the color black], and it also brings a kind of disgrace with it." This student's statement provides a good example of how racist 19th century constructions of the Afro-Brazilian continue to function in everyday discourses. Such symbolically constructed notions about Africa and the Negro in Brazil demonstrate the power of symbolic meanings that craft everyday notions about skin-color and African phenotypes; it is cognitive maps such as this that perpetuate systems of social inequality, poverty, and racism in Brazil. A Moreno male student defined the meaning of Negro as beginning with the Portuguese:

...their enslavement of Indigenas and Negros, and that this memory is passed from generation to generation, because when you say Negro, it is an offense - it is about a person that was thrown into society - it would be like me calling you sour milk. Society hasn't learned that skin color is one thing, but its meaning is something altogether different.

According to one adolescent male, being Negro means not only knowing your social location, but also it implies your social inferiority:

There are those [Negros] who despise their own color. We've learned that if we put our finger on the fire, it will get burnt, and after a while, you learn that, oh, I am of color and my place is here; I won't try to study or go to college or anything. l'll be a nobody because I am Negro and my place is down here.

Knowing one's "própria posição social" (proper social position) also defines one's life possibilities, making it clear that no amount of effort will release you 
from the stigma that the social constructions of racial phenotypes. Those most impacted by racism also define their conceptions of self and others based on the racial hierarchies that limit them. For example, another young male participant (dark moreno) stated:

Negros and pretos discriminate against each other without even knowing it. It's interesting - the ideal woman - for men, you can say that they don't want that morena -skinned, that Negra little girl, they'd rather have the blue-eyed European one, the preference is for the most light-skinned ones, right?

Such narratives of racism demonstrate the effect of Brazil's covert cultural constructions of "race," and reveal how Brazilians of African descent contextualize and narrate their experiences, positioning themselves away from preto on the skin-color spectrum.

In Dreaming Equality: Color, Race, and Racism in Urban Brazil, Sheriff (2001) discusses the negative assumptions embedded in racial terms such as preto and Negro that reflect a lack of social worth, physical aesthetics, and moral stances. My findings reflect Sheriff's statement, "Negro and similar words...simultaneously connote darkness, ugliness, marginality, and immorality...All terms are located, both symbolically and discursively, within a hierarchy that posits both aesthetic and moral values. Negro and preto are at the bottom of this hierarchy" (Sheriff 2001:49).

Based on discussions with my informants and Afro-Brazilian friends, the term Negro is used in the cultural context of Brazilian Portuguese, and constitutes a linguistic conundrum when translated into English. In English, the Brazilian Portuguese term Negro, according to my informants, refers to ethnicity as well as to skin-color tonality, with Negro implying dark to very dark skin, but not "preto" (black) skin color. Therefore, for them, Negro refers to ethnicity both in terms of African heritage and African phenotypes - from a darker to very dark skin color that is lighter than a pure preto (black) skin tonality, and reflects that some racial mixture (miscegenation) has occurred; conversely, preto refers to black skin (no racial mixture) and to phenotypical African features, both of which are the ultimate "signifiers-of-race" in Brazil.

\section{Conclusions}

Do these beliefs accurately represent how Brazilians think about skin color and about their "racial" identity? If asked to agree or disagree, most Brazilians would quickly disagree, and reply "Nós não temos racimo aqui em Brasil. Todo mundo é uma mistura de toda aqui; português, indigena, Negro. América tem racismo!' (We don't have racism in Brazil. Everyone is a mixture of everything here - of Portuguese, Indian, Negro. America has racism!). From early 2000 polls taken in Rio de Janeiro, 93 percent of the respondents stated that racism exists in Brazil, but 87 percent of those respondents said that they were not racist, thus frustrating Black activists who continue to fight the invisible enemy of democracia racial (Buckley 2000). Brazil's racial project continues to be passed on through the historical imagination and national rhetoric about what it means to be Brazilian, and what it means to be Afro-Brazilian. What is a Brazilian's 
color? It is mostly a mixture (mulatto), but it is seldom that Brazilian's selfidentify as preto or African.

How can racism in Brazil be transformed? Perhaps one way to approach this question is by comparing racial transitions between the United States and Brazil. Omi and Winant (1994) employ their theory of racial formations to the minority movement of the 1950s and 1960s in the US. They argue that two important changes were characteristic in US racial politics during these decades:

- A paradigm shift occurred in the constructed meanings of race and racial identities, which led to the civil rights movement.

- The civil rights movement generated new black social movements that contested the nature of racial politics (Omi and Winant 1994:95-98).

I also contend that legalized racism became increasingly controversial in the US after World War II, thus placing the country in an awkward position as leaders in the creation of the United Nations (UN) and the drafting of the Universal Deceleration of Human Rights (UDHR). The obvious nature of legalized racism in the US provided a clear and present admission of racism in a country that had been instrumental in drafting the UNDHR. The ideological support for human rights and the contradiction of them in the US played a significant role in the Civil Rights Movement. No such obvious contradictions were recognized in Brazil, where the ideology of democracia racial alleged that racial relations in Brazil were ideal (Frazier 1992; Freyre 1987).

Another difference between US and Brazilian racism is the lack of successful and on-going Black Pride movements in Brazil. In his study of the Afro-Brazilian activist movement, Hanchard (1994) asks why Black pride movements in Brazil have not generated a similar civil rights movement. Sociologist France Winddance Twine shares Hanchard's curiosity about the failure of Afro-Brazilian activists to create and sustain a Black pride movement such that the ideology of democracia racial is denounced. Winddance Twine's research explores the question of race through "...the perspective of ordinary Brazilians who are not engaged in antiracist activism...[instead of through the lenses of]...historians, sociologists, and political scientists [who] have sought an answer to this paradox by analyzing the elite...the state... or antiracist activists (1998:4-5). My research draws upon her approach, and supports her findings by further illustrating how everyday ordinary Afro-Brazilians think about, feel, and understand their experiences of racism in Brazil's democracia racial, while also addressing the elite's construction of the state's policy of democracia racial.

Participants in my study were aware of the symbolic, metaphorical, and social meanings connected to skin colors - especially darker tonalities. However, other than general knowledge about Africa's colonial subjugation and its subsequent poverty, misery, and "backwardness," my informants were unable to provide stories or historical information about African history that invoked a sense of pride in being African. The lack of popular discourses that valorize African history (not simply candomblé, samba, and carnival) suggest a paucity of African Studies educational programs in Brazilian primary and secondary educational settings, as well as in Brazil's institutions of higher learning. In essence, Brazil's racial project has been more subtle than in the US. Absorbing African and Indigenous bodies into a constructed Brazilian identity that validated 
Western European Enlightenment ideals effectively dissolved the possibility of being Afro-Brazilian. The only viable embodied identity is that of the mulatto or mestiço - whose skin-color and phenotypes reflect Western European aesthetics.

To Brazilian social scientists, racism is both palpable and visible, but is successfully silenced in everyday public life. Popular discourses continue to conceptualize poverty and inequality as a social class issue, yet statistics on health, education, and employment bear out the serious inequities that exist between preto, Negro, and lighter-skinned moreno Brazilians. A female history professor argued that the inferiority of the darker-skinned Afro-Brazilian is tacitly understood because of the pejorative constructions of African phenotypes associated with slavery, and the lack of educational material and curriculums that present non-colonial historical perspectives about Africa and her people: "... it is necessary to remove this mystique of the inferiority of the Negro, of him being less than others. As long as this impression lasts, Negros will be viewed as only slaves." As she implies, the socio-historical racial project in Brazil can be mitigated by social actors identifying their socio-historical past and insisting on re-claiming their stolen identities. Such individual actions can result in forms of social action that refuse to accept the hegemony of everyday "common sense" notions of the ways things are.

My informants' stories reflect the material, temporal, and psychological costs of being an individual with Afro-Brazilian phenotypical traits. Hair, lips, noses, body shapes, and skin colors that reflect African descent are highly stigmatized and even considered offensive, especially for Brazilian women (Baran 2007:388). Like Baran, I did not find these observations to be an anomalous, since they were common among participants in my research. Of interest, however, is the tension between the personal knowledge that racism exists, and the continuation of the dominant popular discourse of democracia racial.

Data in this study reflect the racial consciousness of individuals living in Belo Horizonte across class, age, race, and gender; these data demonstrate that dialogues about racial discrimination and stereotypical perceptions about blacks are consciously known, understood, and even accepted. Why, then, does the myth of democracia racial persist? While the participants in my research are keenly aware of racism in terms of its practices and codes, open public discourses about the ways in which racism functions in Brazil have, until very recently, not become part of classroom discussions or open public debate. Individual experiences with racism are felt and acknowledged, yet repressed. Participants stopped short of converting their feelings into complaints or social activism because they had no faith that the law would provide them with justice. When asked why they didn't report racism in the job market, for example, the most common reply was that nothing would come of their complaint; "laws stay on the paper in Brazil," or "laws function for those who don't need them in Brazil."

To paraphrase Gramsci, hegemony requires the complicity of the oppressed to secure and maintain the necessary social control the nation-state has over them (Buttigieg 1992). While my informants realized that they were denied the same opportunities available to non-racialized groups, their social status, and to some extent, their racial identity has been expertly managed and maintained by the 
hegemonic racial project initiated by the Brazilian nation-state after abolition. Those who experience racism have little recourse and fewer resources with which to transform their false-consciousness.

Brazil's national identity and the ideologies that formed it are embedded in systems of education, the media, religion, informal and formal market places, and within everyday performances of both individual and collective identity. While participants are either partially or largely aware of racism directed at them, they are unable to mobilize their own indignation in ways that publically call attention to their marginalization. In the 1950s, African Brazilian scholar and activist, Abdias do Nascimento, stated that those who believe in Brazil's racial paradise:

do not perceive the subtle socio-psycho-logical theory that has been intricately built and developed over the course of our history, landing those who partake of it in a surrealist labyrinth. This has retarded, but not eradicated, the spectacular emergence of prejudice and its consequent counterpart, also spectacular, the militant reaction of blacks (da Silva Martins, Medeiros, Nascimento 2004:788).

While I have argued that through the social processes of hegemony and false consciousness, the oppressed foment their own oppression, I also argue that the Brazilian racial project can be altered or even reversed when activist social movements gain momentum through the efforts of individual and collective actors in partnership with social institutions. Yet before Black Pride activist movements and open public discourses about race can take root and spread in Brazil, new ideological paradigms about racial identity need to be forged, such that racial identities (different from the nation-state's constructed tri-ethnic racial blend) are validated in individual actors and within social and governmental institutions.

Theoretically, Marx defined "ideology" as a system of ideas that generates thoughts and experiences. Thoughts and experiences in turn are dependent on the physical and symbolic environment in which individuals live. While Marx refers most commonly to commodity production and social relations when discussing ideology, I extend his theory to race relations; "race" is a creation of historical relationships (ideologies), hegemonically constructed as social capital, and extending into all aspects of everyday life (Marx and Engles 2001).

I argue that the historical ideology of Western European twentieth century paradigms of scientific racism and nation building required Brazilians to accept the premise of the biological supremacy of Western European whites. Brazilian nationality rested on the acceptance that "in less than a hundred years Brazil would have no Negroes whereas the U.S. would have the problem of twenty or thirty million" (Winddance Twine 1998:7). Racism in Brazil is ironic, convoluted, and secretive, generating a particularly difficult oxymoron that combines scientific racism with racial miscegenation, while maintaining white superiority. Authenticity through ethnicity has not yet been realized in Brazil.17

To create a counter-ideology capable of initiating a palpable challenge to 
democracia racial might require a recognition of ethnic identities; an "unblending" of Brazil's ambiguously constructed racialized bodies (Nobles 1995).

As my data demonstrate, Brazilians are cognizant of racial categories (phenotypes and skin-colors), while preferring to self-identify in the racially ambiguous category of moreno/a. By self-identifying within Brazil's racially ambiguous moreno/a category, social actors employ the underlying bi-polarity of democracia racial's ideological constructs, and in so doing demonstrate the depth and power of Brazil's structural racial formations. The contradiction between my participants' awareness of racism in their lives, and their proclivity to self-identify most frequently within the tri-racial category of Moreno/a might be attributed to an intermediate state of consciousness, a slippery-slope where no traction can be found, between shifting paradigms that define race in Brazil.

New challenges to existing discourses about race and racialized bodies are expanding, and the term Afro-Brazilian is becoming a common referent for darker-skinned African descendents in social science literature (Bailey 2009; Caldwell 2007; Dávila 2006; Telles 2004; Twine 1998), suggesting that this topic is no longer silenced and that the term itself has dialogic value. Indeed, the intense debate around the implementation of the quota system for Brazilian universities is another indication of the changing ideology of race in Brazil.

A good example of the potential for new paradigmatic ideological formations can be found in a series of historic events that I identify as occurring during the mid-1990s. These events paved the way for a major fracture in the status-quo of the national discourse on race in Brazil:

- In 1995, President Henrique Cardoso began to prepare the way for the dismantling of democracia racial, and in 2005, he declared that racial discrimination against Afro-Brazilians does exist in Brazil. Cardoso became the first Brazilian president to reject publically and officially the myth of Brazil's racial democracy. - The second important event is the Third World Conference on Racism, Racial Discrimination, Xenophobia, and Intolerance, held in Durban, South Africa in 2001. The conference was well attended by black movement Afro-Brazilian activists who exerted considerable pressure on the media to pay attention to the issue of racism in Brazil. By the summer of 2001, the Brazilian media finally began to openly investigate racial discrimination in Brazil. - The third important event occurred in the same year, 2001, when establishing affirmative action plans for college entrance into public universities was proposed. However, the constructions of Brazilian racial identity posed a difficult question: How can one establish programs to favor blacks when we cannot even determine who is black? (dos Santos and Obianuju C. Anya 2006:30-31). This question continues to be the center of debate about race, racism, and racial inequality in Brazil.

Embarking on a plan to define social benefits by "race," seventeen Brazilian universities used quotas in 2003. Instigated at the federal level, this decision has been hotly debated in the popular media (Pimentel 2003; Vogt 2003; Figueredo 2008). However, even with the encouragement of the Federal Ministry of 
Education, only 13.8 percent of new students have entered Brazil's 56 federal universities based on the quota system, and less than half of all the federal universities have an affirmative action program in place (Folha de São Paulo 2006).

The Brazilian government must continue to expand and better implement existing affirmative action and quota system based programs that focus on economic and skin-color criteria for students applying to public and private universities.18 Another important development should be the creation of new funding sources, and expansion of existing accessible financial aid programs with low interest rates and flex payment plans for economically poor students of all ethnicities (most likely, the majority of these students would be of darker skin color with Afro-Brazilian phenotypes or students of indigenous ethnicity). 19

A cyclical process of engagement is necessary to carve out a new paradigm of Brazilian identity, one that acknowledges ethnic differences, and rejects social class as the epicenter and cause of racial and social inequalities. Debates in public forums, on media outlets, and internet chat-rooms between everyday mulatos, pardos, armarelos, indigenous ethnicities, Afro-Brazilians, and those who self-identify as white can foment the expansion and dissemination of information about experiences of racism, notions of racial identity, and identification of racial practices. Politicians, state and federal bureaucrats, financial CEOs and other elites cannot be in charge of leading Brazil into discussions about race and inequality. NGOs, public and private foundations, universities, academic researchers and applied anthropologists, and media activists must continue with their involvement in developing campaigns that support and raise awareness about the historical processes that formed racial attitudes and beliefs that continue to support racism in Brazil. Dismantling democracia racial will require deep and profound structural changes within Brazilian society.

While some Brazilians consider the topic of race to be repugnant, it needs to be openly discussed in the public domain of politics, educational systems, media outlets, film industries, and within the chambers of Brazil's federal and civil courts. Breaking the silence of Brazil's democracia racial will require meaningful social and economic changes at structural levels within government, institutional, and organizational entities that currently perpetuate racial ideologies that reflect colonial treatments of targeted racialized bodies.

What can we learn about racism in the Americas? Brazil's democracia racial and the "one-drop-of-blood-rule" in the United States produced abhorrent systems of racial oppression and human suffering. While some social science scholars argue that the US is moving toward "color-blindness" in terms of "race," and that Brazil is reluctantly accepting university quota systems based on "race," it is clear that both racial systems must be understood in terms of their respective socio-historical constructions (Bonilla-Silva 1999; 2010; Doane and BonillaSilva 2003; Telles 2004). Both used science to inform and construct political economies of racialized practices that produced as yet unacknowledged genocides on both continents.

Unless the "seamier" side of Brazil's socio-historical constructions of "race" 
is exposed, the insights to understand their own cultural inheritance and the ability to reach for authentic equality will be lacking. Without understanding culturally constructed ancestral behaviors from the social and biological sciences and colonial political agendas about "race," societal change toward equality will remain elusive, as will the various acts of reconciliation necessary for healing.

\section{ENDNOTES}

1Since it was identified by research participants as an ethnic identity, the term Negro is capitalized in this paper.

2 In this article, race is considered a cultural construction; not a category that defines physical differences between and across human variation.

3 Democracia racial (racial democracy) is a term frequently used to describe race relations in Brazil. Coined by Freyre in the 1930s, democracia racial formulated the belief that Brazilian's do not view each other through the lens of race. Hence, the term denied that Brazilian's harbor racial prejudice towards one another. Freyre argued that the highly miscegenated tri-racial composition of Brazil's population resulted a racial mixture that equalized social and racial relations. See Skidmore's Black into White (1974) for his dated, but historical text on debunking the Brazilian notion of democracia racial.

4The term moleque refers to a young street child. Originally, the term was used to describe a slave child. During slavery in Brazil, using this term for a white person was extremely offensive since it was a term used only for young slaves (Mikulak 2002; Mikulak 2007a: Mikulak 2007b). Today, this term has a variety of meanings, some of which are no longer considered pejorative or demeaning, depending on the region in Brazil, and the context in which it is used. Trombadinha refers to an individual, usually of young age, who does not have resources for survival, lives on the street, and robs to survive. The term pivete refers to a street child or poor child living on the streets who is dangerous due to his circumstances. Such individuals are seen to be drug users, and to display violent behaviors (Mikulak 2002; Stephens 1999).

5 The term favela refers to communities of economically poor people (often darkerskinned Afro Brazilians) living as squatters in shantytowns (slums) on the periphery of small and large cities in Brazil; the term favelados refers to the population living in Brazil shantytowns.

6Symbolic power is referred to in this article as cognitive maps, constructed by social agents based on socio-historical and hegemonic norms (Boyer 1999).

7 Ethnicity is understood here to refer to cultural expressions that identify difference among marginalized and/or peripheral groups within a nation-state (Sanjek 1971).

8 Other social scientists exploring race relations based on census data include Nobles' (2000) work on the politics of race, censuses, and citizenship, Royal and Dunston's (2004) work on changing paradigms of race due to human genome research, and Andrade's (2003) research on quota systems in Brazilian.

9The meaning of terms to define people-of-color include: caboclos (mixture of white and Indian), sertanejo (peasant from rural northeastern backlands), caipiras (peasant from the rural southeast), and moleque (slave child, person without dignity) (de Holanda Ferreira 1975; Stephens 1999). Each linguistic distinction reflects a symbolic phenotypical appearance.

10The term "personalistic" refers to the doctrine of subjective realism which regards personality, appearance, and social position as the means in which to interpret everyday reality. Mainwaring (1988) provides the following assessment of personalism in Brazilian politics: "One of the factors that has undermined party competition and helped sustain elitist forms of domination in Brazil has been pervasive clientelism. Rather than providing mass entitlements, politicians have generally attempted to win popular support by providing personal favors. Competition is then reduced to personalistic rivalries among those politicians who compete for votes in a given region; it has no programmatic basis. Personal favors and clientelism exist in all political systems, but the extent to which they 
undercut broad-based competition in Brazil is exceptional" (p. 98).

11 While Brazil's slavery has often been touted as less cruel and more benign than slavery in the United States, when slaves were allowed to purchase their freedom and land, the paternalistic relations of patron-client dependency remained in place through a variety of social and institutional practices that include lack of access to quality education, medical care, and social services (Skidmore 2003).

12 For a discussion on polygenesis, monogeneses theories, social Darwinism, Lamarkian evolution, and classical cultural evolutionism see Baker 1998; Jahoda 1999; Schwarcz 1999 and Service 1985.

13The term "minors" was a legal code used to categorize darker-skinned, economically poor street youth, while the term "adolescent" was used to describe lighter-skinned, middle and upper-class youth. Batteries of psychological exams were used to demonstrate the degenerate capacities of minors, and to levy sentences that unjustly incarcerated street youth (Rizzini 1994).

14However, Brazil is making progress in reducing extreme poverty: for example, between 1990 and 2005, extreme poverty was reduced by $12 \%$, and poverty was reduced by $14 \%$ (World Bank 2007).

15Functional Illiteracy refers to less than 4 years of schooling.

16Brazilian educational systems are socially and historically linked to it its colonial history. In Brazil, education began with the Jesuits in 1549, and remained in their hands for 210 years. In 1759, the Jesuits were expelled from Portugal and her colonies, and religious education was transferred from the church to the state. The educational system remained stagnant until the beginning of the 19th century (McCoy 1959). See also Democracy, Authoritarianism, and Education Finance in Brazil (Brown 2002) for a discussion on the military regimes political clout with the private sector for educational funding of public universities at the expense of public primary and secondary education. 17 Warren offers an interesting discussion on the exception to Brazil's tri-racial identity based on the concept of democracia racial. Ironically, according to his research it was the military dictatorship that changed Brazil's policies regarding Indian exorcism (Warren 2001:54-92).

18See Bailey's Legacies of Race: Identities, Attitudes, and Politics in Brazil, particularly chapter 8 on racial sorting for an excellent discussion of the polemics of affirmative action and quota systems (Bailey 2009).

19Other programs such as the Bolsa Familia (a health and school scholarship program for primary and secondary school children), has had some success in impacting poverty stricken families and their children. The program was fully initiated in 2003, and requires children between the ages of $7-15$ to remain in school and to participate in social educational activities throughout the entire day. In exchange for complying with the rules of the program, families of participating children receive a specified monthly income (Ozanira da Silva e Silva 2007).

\section{REFERENCES}

Amaral, Friedrich Ernesto. 2006. "Race Segregation in Brazil: a GIS Approach." http://paa2006.princeton.edu/download.aspx?submissionld=61570, accessed on 8/7/2010.

American Anthropological Association. 1998. "AAA Statement on Race." http://www.aaanet.org/issues/policy-advocacy/AAA-Statement-on-Race.cfm, accessed on 6/18/2010.

Andrade, Eduardo C. 2003. "Quotas in Brazilian Universities: Good or Bad Idea?" Department of Economics Working Paper 303. University of Brazilia. http://www.unb.br/face/eco/cpe/TD/303Aug03EAndrade.pdf, accessed on 3/22/2010

Bailey, Stanley R. 2009. Legacies of Race: Identities, Attitudes, and Politics in Brazil. Stanford: Stanford University Press.

Baker, Lee D. 1998. From Savage to Negro: Anthropology and the Construction of Race, 
1896-1954. Berkeley: University of California Press.

Baran, Michael D. 2007. "'Girl, You Are Not Morena. We Are Negras!': Questioning the Concept of 'Race' in Southern Bahia, Brazil." ETHOS 35: 383-409.

Bonilla-Silva, Edwardo. 1999. "The Essential Social Fact of Race." American Sociological Review 64:899-906.

Bonilla-Silva, Edwardo. 2010. Racism without Racists: Color-Blind Racism and Racial Inequality in Contemporary America. New York: Rowman \& Littlefield.

Borges, Dain. 1993. "'Puffy, Ugly, Slothful and Inert': Degeneration in Brazilian Social Thought, 1880-1940." Journal of Latin American Studies 25: 235-256.

Boyer, Pascal. 1999. "Tracks of Cultural Inheritance: How Evolved Intuitive Ontology Governs Cultural Transmissions." American Anthropologist 100:876-889.

Brinton, Daniel. 1890. "Races and People." Science 16: 276 - 277.

Brown, David, S. 2002. "Democracy, Authoritarianism, and Education Finance in Brazil." Journal of Latin American Studies 34: 115-141.

Buckley, Stephen. 2000. "Brazil's Racial Awakening." The Washington Post http://www.hartford-hwp.com/archives/42/133.html. accessed on 4/5/2010.

Burdick, John. 1998. Blessed Anastacia: Women, Race and Popular Christianity in Brazil. New York: Routledge.

Buttigieg, Joseph A. Ed. 1992. Prison Notebooks. New York: Columbia University Press.

Caldwell, Lilly, Kia. 2007. Negras in Brazil: Re-envisioning Black Women, Citizenship, and the Politics of Identity. New Brunswick: Rutgers University Press.

Vogt, Carlos Con Ciência. 2003. O Brazil negro: Sistema de cotas para negros amplia debate sobre racismo. Atualizado em 10/11/200, http://www.comciencia.br/reportagens/negros/06.shtml. accessed on 2/10/2010.

Dávila, Jerry. 2006. Diploma of Whiteness: Race and Social Policy in Brazil, 19171945. Durham: Duke University Press.

da Silva, Martins, Sérgio and Carlos Alberto Medeiros, Elisa Larkin Nascimento. 2004. "Paving Paradise: The Road from "Racial Democracy" to Affirmative Action in Brazil." Journal of Black Studies 34:787-816.

de Campos Meirelles, Henrique. 2009. "Banco Central do Brasil: Brazil at the Outset of the Crisis." http://www4.bcb.gov.br/pec/appron/apres/HM_NY_agosto2009_v11.pdf. Slide 9. accessed on 4/13/2010.

de Carvalho, José, Alberto, Charles H. Wood, Flávia Cristina, and Drumond Andrade. 2004. "Estimating the Stability of Census-Based Racial/Ethnic Classifications: The Case of Brazil." Population Studies 58: 331-343.

de Gobineau, J. A. 1856. Moral and Intellectual Diversity of Races. Philadelphia: J.B.Lippincott \& Co.

de Holanda Ferreira, Buarque. 1975. Novo Aurélio: O Dicionário da Língua Portuguesa - Século XX1. Rio de Janeiro: Editora Nova Fronteira.

de Paulo Souza, Telma Regina. 2005. unpublished paper. "Para uma politica de reconhecimento identitário." UNIMEP. Doane, Ashley, W \& Bonilla-Silva, Eduardo. 2003. White Out: The Continuing Significance of Racism. New York: Routledge.

do Valle Silva, Nelson \& Carlos Hasenbalg. 2000. "Tendências da Desigualdade Educacional no Brasil." Dados 43 http://www.scielo.br/scielo.php?pid=S0011-52582000000300001\&script=sci_arttext. accessed on 5/14/2010.

dos Santos, Augusto, Sales and Obianuju C. Anya. 2006. "Who is Black in Brazil? A Timely or a False Question in Brazilian Race Relations in the Era of Affirmative Action? Latin American Perspectives." Vol. 33, No. 4: 30-48.

Downie, Andrew. 2005. "In Un-P.C. Brazil, a List of 96 Offensive Terms Causes Offense." Christian Science Monitor May 17. http://www.csmonitor.com/2005/0517/p01s04-woam.html. accessed on February 17, 2010.

Fernandez-Armesto, F. 1987. Before Columbus. London: Macmillan.

Figueredo, Cilene. Brazil! Brazil! 2008. Sistema de cotas já levou mais de 40 mil às 
universidades. http://nogueirajr.blogspot.com/2008/01/sistema-de-cotas-j-levou-maisde40-mil.html. accessed on 3/15/2010.

Fontaine, Pierre-Michel (Ed.). 1985. Race, Class and Power in Brazil. Berkeley, California: Center for Afro-American Studies, University of California Publication Services Department.

Freyre, Gilberto. 1987. Mansions and the Shanties: The Making of Modern Brazil. Berkeley: University of California Press.

Froude, James Anthony. 1895. English Seamen in the 16th Century (new ed.). London: Longmans Green.

Goodman, Alan, Deborah Heath, and M. Susan Lindee (Eds.). 2003. "Human Races in the Context of Recent Human Evolution." Pp. in Anthropology and Science: Beyond the Two Culture Divide - Genetic Nature/Culture. Alan R.Tempelton (Ed.) Berkeley: University of California Press. 240

Gould, Stephen, J. 1996. The Mismeasure of Man. New York: W.W. Norton \& Company. Hale, Charles, R. 1997. "Cultural Politics of Identity in Latin America." Annual Review of Anthropology 26:567-90.

Hanchard, Michael, G. 1994. Orpheus and Power: The Movimento Negro of Rio de Janiero and São Paulo, Brazil, 1945-1988. Princeton: Princeton University Press. Hanchard, Michael, G. (Ed.). 1999. Racial Politics in Contemporary Brazil. Durham: Duke University Press.

Healey, Mark Alen. 2003. "Powers of Misrecognition: Bourdieu and Wacquant on Race in Brazil." Nepantla: Views from South 4: 391-402.

Hellwig, David J. (Ed.). 1992. African American Perspectives on Brazil's Racial Paradise. Part 1, Chapter 5. Philadelphia: Temple University Press. IBGE. 2007. IBGE Cidades @ http://www.ibge.gov.br/cidadesat/default.php. accessed on $5 / 27 / 2010$.

Jahoda, Gustav. 1999. Images of Savages: Ancient Roots of Modern Prejudice in Western Culture. New York: Routledge.

Leal, Victor Nunes. 1977. Coronelismo: The Municipality and Representative Government in Brazil. Cambridge: Cambridge University Press.

Le Bon, Gustave. 1894. Les Lois Psychologiques de l'évolution des Peuples. Paris: Félix Alcan. (The Psychology of Peoples, Trans. anon from the revised and expanded 3rd Edition of 1898. /Macmillan, New York, 1898).

Lloyd, Marion. 2010. "At Universities, Affirmative Action Faces Crucial Test." The Chronicle of Higher Education. August 23. http://chronicle.com/article/At-BrazilsUniversities/123720/ accessed on 8/23/2010.

Lovejoy, A.O. 1936. The Great Chain of Being: A Study of the History of an Idea. Cambridge MA: Harvard University Press.

Lovell, Peggy, A. 2000. 'Gender, Race, and the Struggle for Social Justice in Brazil," In Latin American Perspectives 27: 85-102.

Mainwaring, Scott. 1988. "Political Parties and Democratization in Brazil and the Southern Cone." Comparative Politics 21: 91-120.

Marx, Anthony, W. 1998. Making Race and Nation: A Comparison of the United States, South Africa, and Brazil. Cambridge: Cambridge University Press.

Marx, Karl. 1977. Capital, Volume one. New York: Random House.

Marx, Karl and Frederick Engels. 2001. Introduction to a Critique of Political Economy. New York: International Publishers.

Menand, Louis. 2001. "Morton, Agassiz, and the Origins of Scientific Racism in the United States." The Journal of Blacks in Higher Education 34:110-113.

McCoy, Don, B. 1959. "Education in Brazil." Peabody Journal of Education 37: 39-43.

Mikulak, Marcia. 2002. The Social Construction of Disposable Children: Street and Working Children in Curvelo, Minas Gerais, Brazil. Ann Arbor: ProQuest (UMI Dissertation Services).

Mikulak, Marcia. 2007a. "Love and Suffering in Bom Jesus: Marileia as Favela Woman and Mother." Bulgarian Journal of American and Transatlantic Studies 2:2-10.

Mikulak, Marcia. 2007b. "The Political Economy of Everyday Life: Working Children in 
Minas Gerais, Brazil." Journal of Humanities and Social Sciences 1:1-21

Morley, Samuel, A. 2005. "Reducing Poverty in Brazil: Lessons Learned and Challenges for the Future." United States Agency for International Development (USAID). http://www.povertyfrontiers.org/ev_en.php?ID=1514_201\&ID2=DO_TOPIC. accessed 3/3/2010.

Nagengast, Carole. 1994. "Violence, Terror, and the Crisis of the State." Annual Review of Anthropology 23: 109-136.

Nobles, Melissa. 1995. Responding with Good Sense: The Politics of Race and Censuses in Contemporary Brazil. Yale University 1995. Unpublished PhD Dissertation

Nobles, Melissa. 2000. Shades of Citizenship: Race and the Census in Modern Politics. Stanford: Stanford University Press.

Omi, Michael \& Howard Winant. 1994. Racial Formation in the United States: From the 1960 s to the 1990s. New York: Routledge.

Ozanira da Silva e Silva, Maria. 2007. "O Bolsa Família: problematizando questões centrais na política de transferência de renda no Brasil." Ciência \& Saúde Coletiva 12:1429-1439.

Paixão, Marcelo. 2004. "Waiting for the Sun: An Account of the (Precarious) Social Situation of the African Descendant Population in Contemporary Brazil." Journal of Black Studies 34:743-765

Pimentel, Carolina. Brazzil Magazine. 2003. Brazil Does Not Want a Quota System from Russia. Wed., 13 October. http://www.brazzilmag.com/content/view/383/41/. accessed on $4 / 8 / 2010$.

Powell, J. W. 1888. "From Barbarism to Civilization." American Anthropologists 1: 97-

123.

Prado, Caio, Jr. 1966. A Revolução Brasileira. São Paulo: Editora Brasiliense.

Ramos, Italo. 2006. "Affirmative Action in Brazil: Day of the Lambs." The Black Commentator, 172:1-5

Reichmann, Rebecca (Ed.). 1999. Race in Contemporary Brazil. Pennsylvania: The University of Pennsylvania Press.

Ribeiro, Darcy. 2000. The Brazilian People: The Formation and Meaning of Brazil. Gainsville: University Press of Florida.

Rizzini, Irene. 1994. Children in Brazil Today: A Challenge for the Third Millennium. Rio de Janeiro: Editora Universitaria Santa Ursula.

Rodriguez, Clara, E. \& Hector Cordero-Guzman. 1992. "Placing Race in Context, in Ethnic and Racial Studies" 14: .523-542

Rodrigues, Nina. 1976. Os Africanos no Brasil. 4 ed.. São Paulo: Cia. Editora Nacional.

Rothblatt, Jennifer. 1998. "O Crioulo! Addressee Terms that Address Race Relations in Brazil." Unpublished paper. http://www.udc.es/dep/lx/cac/aaa1998/rothblatt.htm. Accessed on 4/26/2010.

Royal, Charmaine, D. M. and Georgia M Dunston. 2004. "Changing the Paradigm from 'Race' to Human Genome Variation" Nature Genetics 36, S5 - S7.

Sanjek, R. 1971. "Brazilian Racial Terms: Some Aspects of Meaning and Learning." American Anthropologist 73:1126-1143.

Sansone, Livio. 2003. Blackness Without Ethnicity: Constructing Race in Brazil. New York: Palgrave Macmillian.

Schwarcz, Moritz, Lilia. 1999. The Spectacle of the Races: Scientists, Institutions, and the Race Question in Brazil, 1870-1930. New York: Hill and Wang.

Segato, R. L. 1998. "The Color-Blind Subject of Myth; Or, Where to Find Africa in the Nation." Annual Review of Anthropology 27: 129-151.

Service, Elman, R. 1985. A Century of Controversy: Ethnological Issues from 1860 to 1960. Orlando: Academic Press, Inc.

Sheriff, Robin. 1997. "Negro is a Nickname that the Whites Gave to the Blacks": Discourses on Color, Race and Racism in Rio de Janeiro. Unpublished dissertation.

Sheriff, Robin. 2000. "Exposing Silence as Cultural Censorship: A Brazilian Case." American Anthropologist 101:114-132.

Sheriff, Robin. 2001. Dreaming Equality: Color, Race, and Racism in Urban Brazil. New 
Brunswick: Rutgers University Press.

Skidmore, Thomas, E. 1995. Black into White: Race and Nationality in Brazilian Thought. Durham: Duke University Press.

Skidmore, Thomas, E. 1999. Brazil: Five Centuries of Change. New York: Oxford University Press.

Skidmore, Thomas, E. 2003." Racial Mixture and Affirmative Action: The Cases of Brazil and the United States." The American Historical Review 108: 1391-1396.

Skidmore, Thomas, E. 2004. "Brazil's Persistent Income Inequality: Lessons from History." Latin American Politics and Society 46: 133-150.

Stephens, Thomas, M. 1999. Dictionary of Latin American Racial and Ethnic Terminology. Gainsville: University Press of Florida.

Telles, Edward, E. 1995. "Who Are the Morenas?" Social Forces 73:1609-1611.

Telles, Edward, E. 2004. Race in Another America: The Significance of Skin Color in Brazil. Princeton: Princeton University Press.

Twine, Francine Winddance. 1998. Racism in a Racial Democracy: The Maintenance of White Supremacy in Brazil. New Brunswick, NJ: Rutgers University Press.

Tytler, G. 1982. Physiognomy in the European Novel: Faces and Fortunes. Princeton, NJ: Princeton University Press.

UNICEF. 2004. "Economic and Social Council: Summary of Mid-term Reviews and Major Evaluations of Country Programmes - Americas and the Caribbean region." http://www.unicef.org/about/execboard/files/05-PL25_TACRO.pdf. Accessed on $1 / 9 / 2010$.

Winant, Howard. 2000. "Race and Race Theory." Annual Review of Sociology 26:169185.

Warren, Jonathan, W. 2001. Racial Revolutions: Antiracism \& Indian Resurgence in Brazil. Durham: Duke University Press.

World Bank. 2004. "Inequality and Economic Development in Brazil." A World Bank Country Study. The International Bank for Reconstruction and Development, Washington, DC: The World Bank.

http://wwwwds.worldbank.org/servlet/WDSContentServer/WDSP/IB/2004/10/05 /000012009_20041005095126/Rendered/PDF/301140PAPEROInequality0Brazil.pdf. accessed on $5 / 26 / 2010$.

World Bank. 2007. "Brazil Country Brief." http://web.worldbank.org/WBSITE/EXTERNAL/COUNTRIES/LACEXT/ BRAZILEXTN/0, menuPK:322351 pagePK:141132 piPK:141107 theSitePK: $322341,00 . \mathrm{html}$. accessed 5/10/2010.

Wright, Robin. 2002. "Historical and Anthropological Perspectives on the Formation of Cultural Identity." Ethnohistory 49:703-71. 